\title{
Status Daya Dukung Lahan untuk Keberlanjutan Pangan di Kabupaten Klungkung
}

\section{(Land Carrying Capacity for Food Sustainability in Klungkung Regency)}

\author{
Nyoman Sudipa* \\ (Diterima Oktober 2020/Disetujui Agustus 2021)
}

\begin{abstract}
ABSTRAK
Lahan merupakan komponen penting bagi keberlangsungan kehidupan manusia. Pertumbuhan penduduk dan urbanisasi memengaruhi ketersediaan lahan di suatu daerah. Lahan tidak pernah bertambah, tetapi kebutuhan akan lahan terus bertambah setiap tahun, dialihfungsikan menjadi perumahan dan fasilitas lainnya. Sebagai daerah yang terus berkembang, ketersediaan lahan di Kabupaten Klungkung menurun akibat kegiatan pembangunan dan investasi, khususnya investasi pariwisata dan pembangunan sarana penunjang pariwisata dan pengembangan wilayah lainnya. Ketersediaan lahan di sini terus mengalami tekanan yang berdampak pada kemampuan menyediakan pangan. Penelitian ini bertujuan menentukan kebutuhan lahan, ketersediaan lahan, dan status daya dukung lahan di Kabupaten Klungkung sebagai bahan pertimbangan pengambil kebijakan dalam mendukung pangan berkelanjutan setempat. Penelitian ini menggunakan pendekatan kuantitatif dengan menggunakan data primer yang berasal dari pengamatan di lapangan dan data sekunder yang berasal dari data pemerintah serta data penelitian sebelumnya. Hasil penelitian menunjukkan bahwa status daya dukung lahan di Kabupaten Klungkung defisit berdasarkan hasil proyeksi tahun 2021 hingga 2030. Untuk mengatasi defisit lahan, perlu diupayakan peningkatan produktivitas lahan dengan memanfaatkan lahan secara efektif dan alih teknologi.
\end{abstract}

Kata kunci: alih fungsi lahan, daya dukung lahan, Kabupaten Klungkung, keberlanjutan pangan

\section{ABSTRACT}

Land is an essential component for the sustainability of human life. Population growth and urbanization affect the availability of land in an area. Therefore, the land never increases, but the need for land continues to grow every year, converted to housing and other facilities. As an area that continues to develop, Klungkung Regency has decreased the availability of land due to development and investment activities, especially tourism investment and the construction of other supporting facilities for tourism and regional development. Therefore, the availability of land in Klungkung Regency continues to experience pressure, which impacts the ability to provide food. This study aims to determine land requirements, land availability, and land carrying capacity status in Klungkung Regency, which the policy-makers can consider to support food sustainability in Klungkung Regency. This study uses a quantitative approach using primary data from direct observations in the field and secondary data from government and previous research. The results show that the carrying capacity of land in the Klungkung Regency is in deficit based on the projections for 2021 to 2030 . In overcoming the land deficit, it is necessary to increase land productivity by using land effectively and technology transfer to increase food productivity.

Keywords: carrying capacity, food sustainability, Klungkung Regency land conversion

\section{PENDAHULUAN}

Kabupaten Klungkung yang merupakan bagian Provinsi Bali mempunyai daya tarik kuat, terutama daya tarik akan keindahan alam dan budaya yang muaranya adalah daya tarik pariwisata. Dengan ditetapkannya Peraturan Daerah No. 3 tahun 2020 tentang Perubahan atas Peraturan Daerah Nomor 16 Tahun 2009 tentang Rencana Tata Ruang Wilayah Provinsi Bali tentang Perubahan Atas Peraturan Daerah Nomor 16 Tahun 2009 tentang Rencana Tata Ruang Wilayah Provinsi Bali, ada perubahan penetap-

Fakultas Teknik, Universitas Mahendradatta, Jl. Ken Arok No. 12, Peguyangan, Denpasar Utara, Bali, 80115

* Penulis Korespondensi:

Email: nyoman_sudipa@yahoo.com an kawasan, yaitu Kawasan Pariwisata Tegal Besar Goa Lawah, yang sebelumnya telah ditetapkan Kawasan Pariwisata Klungkung. Pariwisata identik dengan penyerapan tenaga kerja dan urbanisasi yang memicu pertumbuhan jumlah penduduk, peningkatan taraf hidup, dan pertumbuhan ekonomi. Hal ini akan meningkatkan kebutuhan akan lahan dan alih fungsi lahan (Sudipa et al. 2020a). Pertumbuhan pariwisata berdampak pada penurunan ekologi lingkungan (Limbong \& Soetomo 2014).

Lingkungan harus mampu mempertahankan fungsi lahan menurut segi konservasi guna mencegah degradasi (Pramesty et al. 2014). Lahan tidak pernah bertambah akan tetapi kebutuhan akan lahan terus meningkat. Jika pemakaian lahan telah melampaui kemampuan daya dukung lahan, maka lahan tidak dimanfaatkan secara efektif (Moniaga 2011). Perubah- 
an penggunaan lahan yang terjadi mengakibatkan banyaknya lahan yang digunakan tidak sesuai dengan kemampuannya sehingga memengaruhi daya dukung lahan dan kualitas lahannya (Ernamaiyanti et al. 2016). Pertumbuhan penduduk dan peningkatan penggunaan lahan berdampak pada lingkungan hidup (Sudipa et al. 2020b). Masuknya wisatawan sebagai bagian dari penduduk menurunkan nilai daya dukung lahan walaupun tidak nyata Rusna et al. (2011). Penggunaan lahan menurunkan daya dukung lahan yang berdampak negatif pada lingkungan hidup Qian et al. (2015). Terus menurunnya ketersediaan lahan di Kabupaten Klungkung menimbulkan kekhawatiran akan keberlanjutan pangan yang terus berlanjut pada penurunan kualitas lingkungan. Untuk itu diperlukan inventarisasi sumber daya alam (Wijaya et al. 2017). Partisipasi masyarakat besar pengaruhnya dalam mengurangi alih fungsi lahan guna mendukung ketahanan pangan berkelanjutan (Aparicio et al. 2017). Penelitian ini bertujuan memproyeksikan daya dukung lahan di Kabupaten Klungkung sampai rentang waktu tahun 2030 yang selanjutnya dapat digunakan sebagai bahan kebijakan pemerintah setemnpat guna mendukung lahan pertanian berkelanjutan. Penelitian ini diharapkan mampu menggambarkan status daya dukung lahan dan implikasinya dengan perkembangan pembangunan yang dapat digunakan sebagai bahan untuk menyusun perencanaan pembangunan yang mendukung ketahanan pangan melalui perluasan dan diversifikasi pertanian dan pengembangan produk budi daya yang inovatif.

\section{METODOLOGI}

Metode penelitian menggunakan pendekatan kuantitatif berdasarkan data pengamamatan langsung di lapangan, data resmi pemerintah, dan dari penelitian sebelumnya. Data yang diperoleh digunakan sebagai alat analisis penentuan daya dukung lahan berdasarkan kemampuan lahan dan perbandingan antara ketersediaan dan kebutuhan akan lahan (daya dukung lahan). Perbandingan antara ketersediaan dan kebutuhan akan lahan suatu wilayah menentukan keadaan surplus atau defisit dari lahan untuk mendukung kegiatan pembangunan dan pengembangan wilayah.

\section{Proyeksi Jumlah Penduduk}

Untuk perencanaan ke depan, laju pertumbuhan penduduk dijadikan sebagai dasar dalam memproyeksikan jumlah penduduk yang menggambarkan perkembangan jumlah penduduk pada masa yang akan datang. Proyeksi penduduk menggunakan metode bunga berganda yang menggunakan tahun dasar 2018 dan laju pertumbuhan penduduk menurut hasil Sensus Penduduk Tahun 2010, dengan rumus:

$$
P_{n}=P_{0}(1+r)^{n}
$$

$P_{n} \quad$ : jumlah penduduk pada tahun tertentu

$P_{0} \quad$ : jumlah penduduk pada tahun dasar r : angka rata-rata pertumbuhan penduduk

$\mathrm{n} \quad$ : jumlah tahun proyeksi

\section{Ketersediaan Lahan}

Ketersediaan lahan dianalisis menggunakan persamaan yang bersumber dari Peraturan Menteri Lingkungan Hidup Nomor 17 Tahun 2009.

$$
\mathrm{SL}=\frac{\Sigma(\mathrm{Pi} \times \mathrm{Hi})}{\mathrm{Hb}} \times \frac{1}{\mathrm{Ptvb}}
$$

$S \mathrm{~L}$ adalah ketersediaan lahan, $P_{\mathrm{i}}$ adalah produksi aktual setiap jenis komoditas (satuan bergantung pada jenis komoditas). Komoditas yang diperhitungkan meliputi komoditas pertanian, perkebunan, kehutanan, peternakan, dan perikanan, $H_{\mathrm{i}}$ adalah harga satuan setiap jenis komoditas ( $\mathrm{Rp} / \mathrm{satuan}$ ) di tingkat produsen, $H_{\mathrm{b}}$ adalah harga satuan beras $(\mathrm{Rp} / \mathrm{kg})$ di kalangan produsen, dan Ptvb produktivitas beras (kg/ha). Dalam perhitungan ini, faktor konversi yang digunakan untuk menyetarakan produk non-beras adalah harga.

\section{Kebutuhan Lahan}

Persamaan yang digunakan bersumber dari Peraturan Menteri Lingkungan Hidup Nomor 17 Tahun 2009:

$$
D_{\mathrm{L}}=N \times \mathrm{KHLL}
$$

$D\llcorner$ adalah total kebutuhan lahan setara beras (dikonversi dengan satuan komoditas setara harga beras) $\left(H_{\mathrm{a}}\right), N$ adalah jumlah penduduk (orang) dan $K H L_{L}$ adalah luas lahan yang dibutuhkan untuk kebutuhan hidup layak per penduduk dan kebutuhan wisatawan.

\section{Status Daya Dukung Lahan}

Status daya dukung lahan diperoleh dari pembandingan antara ketersediaan lahan (SL) dan kebutuhan lahan (DL).

Bila SL>DL, daya dukung lahan dinyatakan surplus.

Bila $S L<D L$, daya dukung lahan dinyatakan defisit atau terlampaui.

\section{HASIL DAN PEMBAHASAN}

Proyeksi jumlah penduduk ini mengikuti kecenderungan pertumbuhan penduduk dari tahun ke tahun. Penduduk menurut kecamatan tahun 20182020 menurut BPS Kabupaten Klungkung dapat dilihat pada Tabel 1. Dari jumlah penduduk tersebut diproyeksikan jumlah penduduk setempat sampai tahun 2030 (Tabel 2).

\section{Kemampuan Lahan}

Kemampuan lahan adalah penilaian lahan secara sistematis berdasarkan sifat-sifat yang merupakan potensi dan penghambat dalam penggunaannya secara lestari. Analisis kemampuan lahan dipengaruhi oleh ketersediaan air dan penggunaan air (Admadhani 
Tabel 1 Jumlah penduduk Kabupaten Klungkung tahun 2018-2020

\begin{tabular}{clrrr}
\hline \multirow{2}{*}{ No } & \multirow{2}{*}{ Kecamatan } & \multicolumn{3}{c}{ Tahun } \\
\cline { 3 - 4 } & & 2018 & 2019 & \multicolumn{1}{c}{2020} \\
\hline 1 & Nusa Penida & 45.580 & 45.610 & 45.660 \\
2 & Banjarangkan & 39.450 & 39.690 & 39.910 \\
3 & Klungkung & 58.550 & 58.930 & 59.290 \\
4 & Dawan & 34.720 & 34.870 & 35.040 \\
& Jumlah & 178.300 & 179.100 & 179.900 \\
\hline
\end{tabular}

Sumber: BPS Kabupaten Klungkung

Tabel 2 Proyeksi jumlah penduduk Kabupaten Klungkung tahun 2021-2030

\begin{tabular}{cccccc}
\hline No & Tahun & $\begin{array}{c}\text { Jumlah } \\
\text { penduduk }\end{array}$ & No & Tahun & $\begin{array}{c}\text { Jumlah } \\
\text { penduduk }\end{array}$ \\
\hline 1 & 2021 & 180.702 & 6 & 2026 & 184.765 \\
2 & 2022 & 181.507 & 7 & 2027 & 185.588 \\
3 & 2023 & 182.316 & 8 & 2028 & 186.415 \\
4 & 2024 & 183.129 & 9 & 2029 & 187.246 \\
\hline
\end{tabular}

et al. 2014). Analisis kemampuan lahan ini, mencakup analisis mengenai sifat tanah (fisik dan kimia), topografi, drainase, kedalaman tanah, dan kondisi lingkungan hidup lainnya. Kemampuan lahan di Kabupaten Klungkung semakin berkurang karena tumbuhnya industri pariwisata yang menurunkan nilai daya dukung air dan lahan (Kang et al. 2012). Penurunan sumber daya air akan berdampak pada kemampuan lahan untuk meningkatkan produktivitasnya (Lu et al. 2017). Berdasarkan karakteristik lahan tersebut, kemampuan lahan diklasifikasi berdasarkan kedalaman tingkat kelas, subkelas, dan unit pengelolaannya. Kemampuan lahan terus berubah akibat perubahan penggunaan Iahan (Adnyana \& As-syakur 2012). Kemampuan lahan sangat berkaitan dengan "tingkat bahaya kerusakan" dan "hambatan dalam mengelola lahan". Klasifikasi kemampuan lahan dikelompokkan ke dalam 8 kelas, dari kelas I sampai kelas VIII. Dalam hal ini, apabila tingkat bahaya (risiko) kerusakan dan hambatan penggunaan meningkat, maka spektrum penggunaan lahan menurun. Kelas kemampuan lahan terbagi atas 8 kelas. Kelas I sampai IV lahan dapat digunakan untuk pertanian, sedangkan kelas V sampai VII lahan untuk padang rumput, dan kelas VIII sebaiknya secara alami sebagai hutan lindung. Setiap kelas dibagi lagi menjadi 4 subkelas, yaitu subkelas erosi, genangan air, solum (penghambat perakaran), dan iklim. Subkelas dapat diuraikan lagi menjadi beberapa unit klasifikasi kelas lahan dan penggunaannya. Dari analisis, diketahui kemampuan lahan wilayah Kabupaten Klungkung terkelompok menjadi 8 kelas. Kelas paling luas adalah kelas VI, yaitu 7796 ha $(24,75 \%)$, disusul kelas III seluas 6.346 ha $(20,15 \%)$, kelas IV seluas 5304 $(16,84 \%)$, dan kelas VIII seluas 3366 ha $(10,69 \%)$. Sementara itu lahan kelas I dan kelas II relatif sempit, yaitu masing-masing 2649 ha dan 3.053 ha. Terdapat pula lahan kelas $\mathrm{V}$ yang merupakan lahan rawa mangrove seluas 224 ha $(0,71 \%)$.

Kemampuan lahan menurut kecamatan sebagaimana Tabel 3 menunjukkan perbedaan yang nyata antarkecamatan. Kecamatan Banjarangkan dan Klungkung didominasi oleh kategori kelas I sampai IV, yaitu masing-masing mencapai $86,05 \%$ dan $89,23 \%$. Sementara kemampuan lahan di Kecamatan Dawan dan Klungkung didominasi kelas VI sampai VIII, masing-masing $54,45 \%$ dan $51,55 \%$. Klasifikasi kemampuan lahan menurut kecamatan di Kabupaten Klungkung dapat dilihat pada Tabel 3 dan dipetakan pada Gambar 1.

Lahan kelas I relatif sempit, yakni 2.649 ha $(8,41 \%)$, dan hanya terdapat di daerah dataran rendah Kecamatan Banjarangkan, Klungkung, dan Dawan, sementara di Klungkung tidak ada lahan kelas I. Demikian juga lahan kelas II, luasnya relatif kecil, yaitu 3053 ha $(9,69 \%)$, tersebar di semua kecamatan, dengan lahan terluas di Banjarangkan (34,11\% dari luas wilayahnya), sementara di Klungkung luasnya hanya 216 ha $(1,06 \%$ luas wilayah). Lahan kelas II di Kecamatan Klungkung hanya terdapat di Nusa Lembongan. Lahan kelas I dan kelas II ini mempunyai sedikit faktor pembatas dan secara umum dapat dimanfaatkan untuk berbagai keperluan seperti tanaman budi daya pertanian dan permukiman. Di daerah hulu, kemampuan lahan semakin menurun. Kemampuan lahan kelas III dicirikan oleh faktor pembatas lereng agak miring $\left(8-15^{\circ}\right)$, kedalaman tanah 50-90 cm, dan tekstur agak kasar. Lahan kelas III merupakan terluas kedua, yakni 6.346 ha $\left(20,15^{\circ}\right)$, menyebar di lereng perbukitan dan sekitar aliran sungai di semua kecamatan. Lahan ini dapat digunakan untuk budi daya tanaman pertanian dan non-pertanian seperti permukiman dan pariwisata. Kemampuan lahan kelas IV dengan faktor pembatas lereng miring berbukit terdapat di semua kecamatan. Luasnya 5.304 ha atau 16,84․ Kategori lahan kelas IV terluas di Klungkung. Lahan ini dapat dimanfaatkan untuk pertanian tanaman semusim, tanaman perkebunan atau tanaman pohon-pohonan, selain untuk kegiatan non-pertanian. Lahan kelas $\mathrm{V}$ dengan faktor pembatas drainase yang buruk menyebar di Nusa Lembongan dengan luas 224 ha, yang merupakan kawasan hutan mangrove. Pemanfaatan lahan telah

Tabel 3 Klasifikasi kemampuan lahan menurut Kecamatan di Kabupaten Klungkung

\begin{tabular}{llcccccccc}
\hline \multirow{2}{*}{ No } & \multirow{2}{*}{ Kecamatan } & \multicolumn{7}{c}{ Kelas kemampuan lahan (ha) } \\
\cline { 2 - 9 } & & $\mathrm{I}$ & $\mathrm{II}$ & $\mathrm{III}$ & $\mathrm{IV}$ & $\mathrm{V}$ & $\mathrm{VI}$ & VII & VIII \\
\hline 1 & Klungkung & 0 & 216 & 4577 & 4222 & 224 & 6686 & 1737 & 2622 \\
2 & Banjarangkan & 808 & 1560 & 835 & 732 & 0 & 261 & 377 & 0 \\
3 & Klungkung & 944 & 808 & 573 & 268 & 0 & 238 & 75 & 0 \\
4 & Dawan & 897 & 471 & 361 & 82 & 0 & 610 & 573 & 744 \\
& Jumlah & 2649 & 3053 & 6346 & 5304 & 224 & 7796 & 2761 & 3366 \\
\hline
\end{tabular}




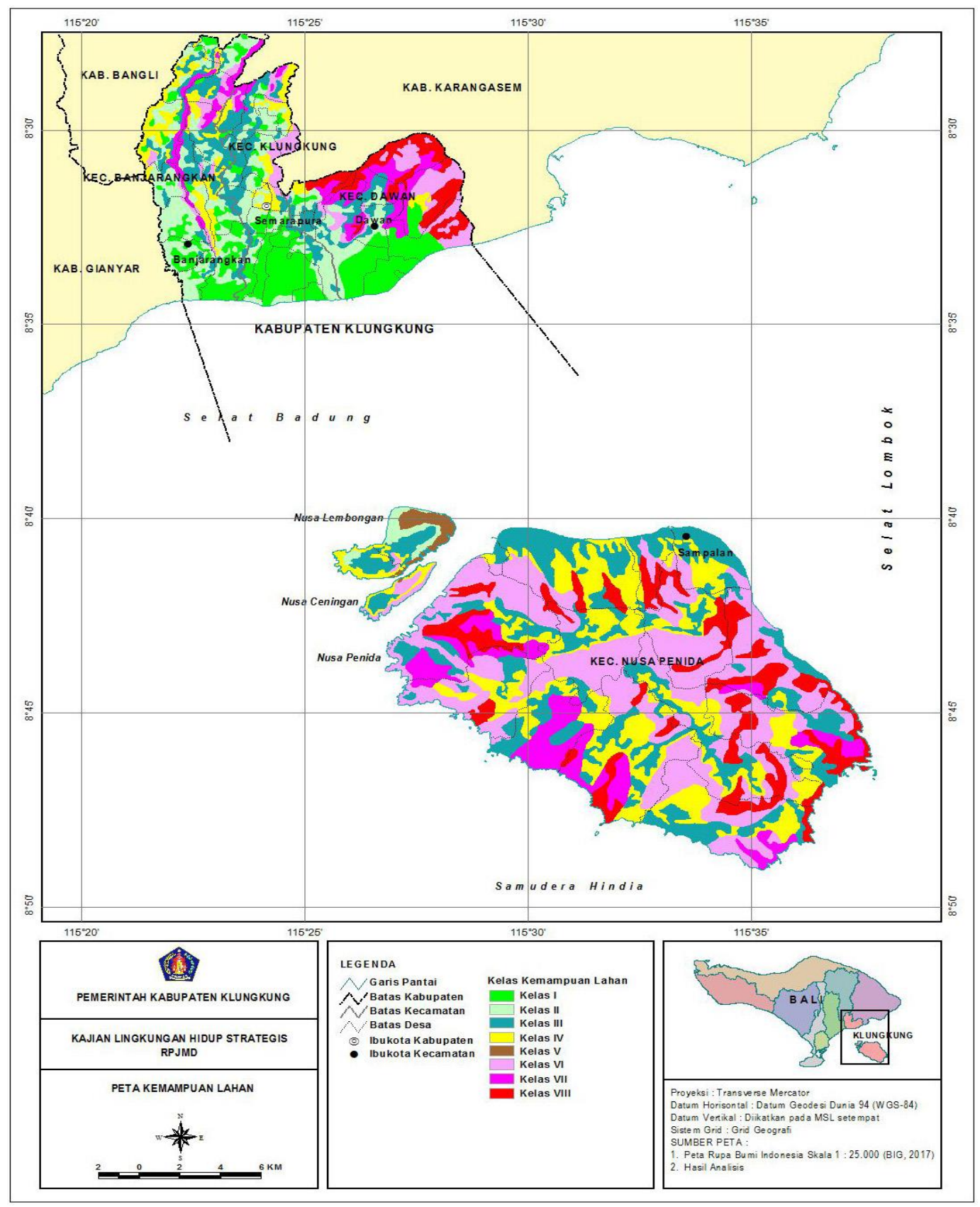

Gambar 1 Peta kemampuan lahan wilayah Kabupaten Klungkung

tepat sebagai kawasan hutan lindung. Lahan kelas $\mathrm{VI}$ merupakan kelas lahan terluas, yaitu 7.796 ha $(24,75 \%)$, tersebar di semua kecamatan, terutama di Klungkung. Faktor pembatas lahan kelas $\mathrm{VI}$ adalah lereng agak curam $\left(30-45^{\circ}\right)$, erosi berat, dan kedalaman tanah $<30 \mathrm{~cm}$, menyebar di semua kecamatan. Lahan ini dapat digunakan untuk tanaman perkebunan, tanaman keras atau pohon-pohonan, hutan lindung, cagar alam, untuk kegiatan nonpertanian.

Kelas kemampuan lahan VII dengan faktor pembatas lereng yang curam $\left(45-65^{\circ}\right)$ dan erosi sangat berat menyebar di semua kecamatan. Luasnya mencapai 2761 ha $(8,77 \%)$. Untuk menjaga kelestariannya, lahan ini sebaiknya digunakan untuk perkebunan tanaman keras atau tanaman pohon-pohonan dan vegetasi alami. Kelas kemampuan lahan VIII luasnya 3.366 ha $(10,69 \%)$, faktor pembatasnya adalah lereng yang sangat curam dengan kemiringan $>65^{\circ}$. Lahan ini menyebar di daerah perbukitan di Kecamatan Dawan dan Klungkung. Mengingat lerengnya yang sangat curam, lahan ini sebaiknya hanya digunakan untuk kawasan lindung. Pengelompokan di dalam kelas didasarkan atas intensitas faktor penghambat. Ancaman kerusakan atau hambatan meningkat berturut-turut dari kelas I sampai kelas VIII. Lahan pada kelas I sampai IV dengan pengelolaan yang baik sesuai untuk berbagai penggunaan seperti untuk tanaman pertanian umumnya (tanaman semusim dan tahunan), rumput untuk pakan ternak, padang rumput, dan hutan. Lahan pada kelas V, VI, dan VII sesuai untuk padang rumput, tanaman pohon-pohonan, atau 
vegetasi alami. Lahan dalam kelas VIII sebaiknya dijadikan hutan lindung atau dibiarkan dalam keadaan alami. Memaksimumkan penggunaan lahan kelas I, II, dan III untuk produksi pangan berkelanjutan adalah dengan menerapkan teknologi pertanian seperti teknologi hidroponik dan pertanian tetes yang sudah mulai diterapkan di Kabupaten Klungkung. Kapasitas budi daya pangan ditingkatkan dan kembali kepada budaya agraris masyarakat Bali.

\section{Ketersediaan lahan}

Semakin meningkatnya pembangunan akan menimbulkan tekanan pada lingkungan dan ketersediaan lahan (Cristie et al. 2013). Pertanian ramah lingkungan, efisiensi penggunaan air, dan efisiensi penggunaan energi akan menjamin keberlanjutan lahan pertanian (Rasul 2016). Ketersediaan lahan dihitung berdasarkan Peraturan Menteri Lingkungan Hidup No. 17 Tahun 2009 tentang Pedoman Penentuan Daya Dukung Lingkungan Hidup dalam Penataan Ruang Wilayah. Untuk mendukung ketersediaan lahan perlu ketersediaan air agar sumber daya lahan dapat digunakan untuk mendukung kehidupan (Santoso 2015). Ketersediaan lahan berhubungan dengan pengelolaan sumber daya air (Cahyani et al. 2018). Sumber daya air yang digunakan untuk keperluan pertanian harus terbebas kandungan bahan pencemar yang dapat merusak lahan (Djoharam et al. 2018). Berdasarkan hal tersebut, data yang diperlukan dalam perhitungan ketersediaan lahan ialah produksi aktual setiap jenis komoditas $(P I)$ dan harga beras di tingkat produsen $\left(H_{b}\right)$, harga satuan setiap komoditas di tingkat produsen $\left(H_{i}\right)$, dan produktivitas beras di Kabupaten Klungkung (Ptvb). Perhitungan nilai produksi pangan dan hortikutura serta nilai produksi ternak di Kabupaten Klungkung disajikan pada Tabel 4, dan total nilai produksi setiap komoditasnya dicantumkan pada Tabel 5.

Berdasarkan data dari BPS, dipadukan dengan hasil survei harga satuan beras di tingkat produsen sebesar Rp. 9.200 per kilogram dan rata-rata produksi beras per hektar sebesar $7.900 \mathrm{~kg} / \mathrm{ha}$, dan dengan menggunakan persamaan $\mathrm{S} \mathrm{L}=\frac{\sum(\mathrm{Pi} \mathrm{Hi})}{H b} x \frac{1}{P t v b}$, ketersediaan lahan di Klungkung adalah $15.443,45$ ha.

\section{Kebutuhan lahan}

Kebutuhan lahan adalah kebutuhan hidup minimum. Tekanan penduduk terhadap daya dukung lahan dapat ditentukan berdasarkan nilai perbandingan antara jumlah penduduk dan persentase petani dengan luas lahan minimum untuk hidup layak (Soermarwoto 2001). Luas lahan di Klungkung adalah

Tabel 4 Perhitungan nilai produksi pangan dan hortikutura serta nilai produksi ternak di Kabupaten Klungkung

\begin{tabular}{clc}
\hline No & \multicolumn{1}{c}{ Jenis komoditas } & $\begin{array}{c}\text { Nilai produksi (PixHi) } \\
(\mathrm{Rp})\end{array}$ \\
\hline 1 & Pangan dan hortikultura & 592.622 .850 .000 \\
2 & Ternak & 529.807 .340 .000 \\
\hline & Total & 1.122 .430 .190 .000 \\
\hline
\end{tabular}

315.000 ha. Luas lahan yang diperlukan kebutuhan hidup layak per penduduk merupakan kebutuhan hidup layak per penduduk dibagi produktivitas beras lokal. Menurut Peraturan Menteri Lingkungan Hidup No. 17 Tahun 2009, untuk kebutuhan hidup layak per penduduk menurut kajian konsumsi bahan pokok beras di Indonesia rata-rata $10.00 \mathrm{~kg}$ setara beras/kapita /tahun (BPS 2017). Produktivitas beras di Kecamatan Klungkung adalah $9.700 \mathrm{~kg} / \mathrm{ha} / \mathrm{tahun}$. Jadi, luas lahan yang dibutuhkan untuk kebutuhan hidup layak per penduduk setempat adalah $0,103 \mathrm{ha} /$ orang. Perhitungan kebutuhan lahan di Klungkung menggunakan pendekatan jumlah penduduk setempat dikalikan dengan luas lahan yang dibutuhkan untuk kebutuhan hidup layak per penduduk adalah 0,103 ha/orang.

\section{Status daya dukung lahan}

Status daya dukung lahan diperoleh dari perbandingan antara ketersediaan lahan $(S L)$ dan kebutuhan lahan $\left(D_{\mathrm{L}}\right)$. Berdasarkan Tabel 6 mengenai proyeksi kebutuhan lahan dan ketersediaan lahan di Kabupaten Klungkung, yaitu 5.350 ha, maka status daya dukung lahan di Kabupaten Klungkung dapat dilihat pada Tabel 7.

Status daya dukung lahan di Kabupaten Klungkung mengalami defisit antara 2.000 dan 3.000 ha sampai tahun 2030. Defisit lahan di sini dapat dikurangi dengan meningkatkan produksi pangan, penganekaragaman pangan, dan menjaga kondisi lingkungan hidup (AsSyakur et al. 2011). Daya dukung sangat penting dengan mempertahankan ekologi lingkungan dengan cara mengurangi alih fungsi lahan (Pratama et al. 2016). Di samping itu, untuk meningkatkan produksi pangan perlu digunakan sentuhan teknologi seperti sistem hidroponik, hidroganik, dan sistem tetes, khususnya di daerah kering seperti Nusa Penida, selain memaksimumkan fungsi lahan termasuk lahan pekarangan untuk menghasilkan pangan. Guna mendukung keberlanjutan lahan pertanian diperlukan pertanian ramah lingkungan dan jaminan ketersediaan lahan (Sauve et al. 2016), perubahan ilmu pengetahuan dan teknologi, perubahan kebijakan pemerintahan yang lebih memperhatikan pertanian, perubahan pasar dan ekonomi, dan perubahan perilaku publik (Doyle et al. 2015). Daya dukung lahan memperhatikan status kepemilikan tanah untuk pembangunan rumah dan permasalahan kerentanan kebencanaan (Khrisnamurti et al. 2016).

\section{KESIMPULAN}

Status daya dukung lahan di Kabupaten Klungkung defisit antara 2.000 dan 3.000 ha sampai tahun 2030 . Berdasarkan data kemampuan lahan, penggunaan lahan perlu diefektifkan untuk lahan kelas I, II, dan III guna meningkatkan produktivitas pangan dengan melakukan inovasi dan pendekatan teknologi pertanian seperti hidroponik dan pertanian sistem tetes yang mulai berkembang di Kabupaten Klungkung. Upaya 
Tabel 5 Perhitungan total nilai produksi tiap komoditas di Kabupaten Klungkung

\begin{tabular}{|c|c|c|c|c|}
\hline No & Jenis komoditas & $\begin{array}{l}\text { Produksi aktual (Pi) } \\
(\mathrm{kg})\end{array}$ & $\begin{array}{c}\text { Harga satuan komoditas }(\mathrm{Hi}) \\
(\mathrm{Rp} / \mathrm{kg})\end{array}$ & $\begin{array}{l}\text { Nilai produksi (PixHi) } \\
(\mathrm{Rp})\end{array}$ \\
\hline 1 & Padi & 29.985 .000 & 5.500 & 164.917 .500 .000 \\
\hline 2 & Jagung & 9.124 .000 & 4.600 & 41.970 .400 .000 \\
\hline 3 & Kedelai & 1.242 .000 & 10.000 & 12.420 .000 .000 \\
\hline 4 & Ubi kayu & 9.466 .000 & 3.800 & 35.970 .800 .000 \\
\hline 5 & Kacang tanah & 1.246 .000 & 8.000 & 9.968 .000 .000 \\
\hline 6 & Ubi jalar & 591.000 & 3.000 & 1.773 .000 .000 \\
\hline 7 & Kacang hijau & 43.000 & 10.000 & 430.000 .000 \\
\hline 8 & Kacang merah & 63.000 & 12.000 & 756.000 .000 \\
\hline 9 & Bawang merah & 1.200 & 40.000 & 48.000 .000 \\
\hline 10 & Cabai & 1.160 .600 & 20.000 & 23.212 .000 .000 \\
\hline 11 & Petsai & 8.964 .900 & 12.000 & 107.578 .800 .000 \\
\hline 12 & Kacang panjang & 23.500 & 9.000 & 211.500 .000 \\
\hline 13 & Ketimun & 3.188 .300 & 5.000 & $15.941 .500,000$ \\
\hline 14 & Terong & 24.100 & 5.000 & 120.500 .000 \\
\hline 15 & Kunyit & 1.1640 & 10.000 & 116.400 .000 \\
\hline 16 & Undis & 38.000 & 15.000 & 570.000 .000 \\
\hline 17 & Mangga & 3.389 .500 & 15.000 & 50.842 .500 .000 \\
\hline 18 & Durian & 358.900 & 10.000 & 3.589 .000 .000 \\
\hline 19 & Salak & 27.600 & 8.000 & 220.800 .000 \\
\hline 20 & Alpukat & 24.900 & 10.000 & 249.000 .000 \\
\hline 21 & Belimbing & 25.200 & 15.000 & 378.000 .000 \\
\hline 22 & Duku & 36.600 & 11.000 & 402.600 .000 \\
\hline 23 & Jambu biji & 79.600 & 12.000 & 955.200 .000 \\
\hline 24 & Jeruk & 79.000 & 12.000 & 948.000 .000 \\
\hline 25 & Jeruk siam & 64.300 & 12.000 & 771.600 .000 \\
\hline 26 & Jeruk besar & 15.200 & 12.000 & 182.400 .000 \\
\hline 27 & Manggis & 156.100 & 20.000 & 3.122 .000 .000 \\
\hline 28 & Rambutan & 96.400 & 6.000 & 578.400 .000 \\
\hline 29 & Sirsak & 36.400 & 9.000 & 327.600 .000 \\
\hline 30 & Sukun & 3.100 & 5.000 & 15.500 .000 \\
\hline 31 & Melinjo & 4.100 & 30.000 & 123.000 .000 \\
\hline 32 & Kopi & 21.640 & 40.000 & 865.600 .000 \\
\hline 33 & Kakao & 22.470 & 45.000 & 1.011 .150 .000 \\
\hline 34 & Cengkih & 76.060 & 100.000 & 7.606 .000 .000 \\
\hline 35 & Jambu air & 11.900 & 6.500 & 77.350 .000 \\
\hline 36 & Sawo & 279.100 & 12.000 & 3.349 .200 .000 \\
\hline 37 & Nanas & 84.100 & 5.000 & 420.500 .000 \\
\hline 38 & Silik & 4.000 & 8.000 & 32.000 .000 \\
\hline 39 & Pepaya & 878.400 & 5.000 & $4.392 .000,000$ \\
\hline 40 & Pisang & 7.714 .800 & 10.000 & $77.148 .000,000$ \\
\hline 41 & Jambu biji & 6.200 & 8.000 & 49.600 .000 \\
\hline 42 & Nangka & 26.900 & 5.500 & 147.950 .000 \\
\hline 43 & Kelapa & 4.329 .000 & 4.000 & 17.316 .000 .000 \\
\hline 44 & Jambu mete & 59.900 & 2.5000 & 1.497 .500 .000 \\
\hline 45 & Sapi & 42.947 & 9.500 .000 & 407.996 .500 .000 \\
\hline 46 & Kambing & 1.023 & 3.000 .000 & 3.069 .000 .000 \\
\hline 47 & Babi lokal & 17.723 & 2.000 .000 & 35.446 .000 .000 \\
\hline 48 & Babi sadle back & 15.220 & 3.000 .000 & 45.660 .000 .000 \\
\hline 49 & Ayam kampung & 129.948 & 80.000 & 10.395 .840 .000 \\
\hline 50 & Ayam petelur & 56.360 & 35.000 & 1.972 .600 .000 \\
\hline 51 & Ayam pedaging & 531.300 & 40.000 & 21.252 .000 .000 \\
\hline \multirow[t]{2}{*}{52} & Itik & 40.154 & 100.000 & 4.015 .400 .000 \\
\hline & Total & & & 1.122 .430 .190 .000 \\
\hline
\end{tabular}

Sumber: Klungkung dalam Angka 2019 dan hasil survei

lain ialah membangunkan kembali lahan-lahan tidur untuk peningkatan produksi pangan, mengaktifkan kembali lahan pekarangan, penganekaragaman pangan, dan program pemerintah yang berupa dukungan program dan anggaran kepada sektor pertanian. Esensi penelitian ini adalah untuk memberikan gambaran tentang daya dukung lahan di Kabupaten Klungkung dan untuk menggugah empati semua pemangku kepentingan kepada pertanian dan ketahanan pangan.

\section{UCAPAN TERIMA KASIH}

Ucapan terima kasih disampaikan kepada pihak yang telah memberi dukungan survei dan data di 
Tabel 6 Proyeksi kebutuhan lahan di Klungkung

\begin{tabular}{ccc}
\hline No & Tahun & $\begin{array}{c}\text { Proyeksi kebutuhan lahan di Kabupaten } \\
\text { Klungkung (ha) }\end{array}$ \\
\hline 1 & 2021 & $18.612,31$ \\
2 & 2022 & $18.695,22$ \\
3 & 2023 & $18.778,55$ \\
4 & 2024 & $18.862,29$ \\
5 & 2025 & $18.946,34$ \\
6 & 2026 & $19.030,80$ \\
7 & 2027 & $19.115,56$ \\
8 & 2028 & $19.200,75$ \\
9 & 2029 & $19.286,34$ \\
10 & 2030 & $19.372,34$ \\
\hline
\end{tabular}

Tabel 7 Status daya dukung lahan di Kabupaten Klungkung

\begin{tabular}{ccccc}
\hline No & Tahun & $\begin{array}{c}\text { Proyeksi } \\
\text { kebutuhan } \\
\text { lahan (ha) }\end{array}$ & $\begin{array}{c}\text { Ketersediaan } \\
\text { lahan } \\
\text { (ha) }\end{array}$ & $\begin{array}{c}\text { Status daya } \\
\text { dukung } \\
\text { lahan }\end{array}$ \\
\hline 1 & 2021 & $18.612,31$ & $15.443,45$ & Defisit \\
2 & 2022 & $18.695,22$ & $15.443,45$ & Defisit \\
3 & 2023 & $18.778,55$ & $15.443,45$ & Defisit \\
4 & 2024 & $18.862,29$ & $15.443,45$ & Defisit \\
5 & 2025 & $18.946,34$ & $15.443,45$ & Defisit \\
6 & 2026 & $19.030,80$ & $15.443,45$ & Defisit \\
7 & 2027 & $19.115,56$ & $15.443,45$ & Defisit \\
8 & 2028 & $19.200,75$ & $15.443,45$ & Defisit \\
9 & 2029 & $19.286,34$ & $15.443,45$ & Defisit \\
10 & 2030 & $19.372,34$ & $15.443,45$ & Defisit \\
\hline
\end{tabular}

lapangan. Penghargaan juga disampaikan kepada Pemerintah Daerah Kabupaten Klungkung dan BPS Kabupaten Klungkung yang telah menyediakan data pendukung.

\section{DAFTAR PUSTAKA}

Admadhani DN, Haji ATS, Susanawati LD. 2014. Analisis ketersediaan dan kebutuhan air untuk daya dukung lingkungan (studi kasus Kota Malang). Jurnal Sumber Daya Alam dan Lingkungan. 1(3): 13-20.

Adnyana IWS, As-syakur AR. 2012. Aplikasi sistem informasi geografi (SIG) berbasis data raster untuk pengkelasan kemampuan lahan di Provinsi Bali dengan metode nilai piksel pembeda; Jurnal Manusia dan Lingkungan: 19(1): 21-29.

Aparicio SL, Vogt M, Schneider P, Tani MK, Broberg A. 2017. Public participation GIS for improving wood burning emissions from residential heating and urban environmental management. Journal of Environmental Management. 191: 179-188. https ://doi.org/10.1016/j.jenvman.2017.01.018

As-Syakur AR, Adnyana IWS, Suarna IW. 2011. Daya dukung lahan Provinsi Bali berdasarkan jejak ekologis. Di dalam: Adnyana IWS, Arthana IW, AsSyakur AR, editor. Denpasar (ID): Pusat Penelitian Lingkungan Hidup. Universitas Udayana. p 77-85.

[BPS] Badan Pusat Statistik Nasional. 2017. Kajian Konsumsi Bahan Pokok tahun 2017. Jakarta (ID).
Cahyani NJ, Dibia IN, Trigunasih NM. 2018. Analisis daya dukung air tanah untuk kebutuhan dometik dan pariwisata di Kota Denpasar. E-Jurnal Agroekoteknologi Tropika. 7(1): 34-43.

Cristie YA, Sina L, Erawati R. 2013. Dampak kerusakan lingkungan akibat aktivitas pembangunan rumah (studi kasus di Perumahan Palaran City oleh PT Kusuma Hady Property) Jurnal Beraja Niti. 2(1): $1-4$.

Djoharam V, Riani E, Yani M. 2018. Analisis kualitas air dan daya tampung beban pencemaran Sungai Pesanggaran di Wilayah Provinsi DKI Jakarta. Jurnal Pengelolaan Sumberdaya Alam dan Lingkungan. 8(1): 127-133. https://doi.org/10.292 44/jpsl.8.1.127-133

Doyle MW, Windheim JP. 2015. Environmental management strategy: four forces analysis; Environmental Management Journal. 55(1): 6-18. https://doi.org/10.1007/s00267-014-0389-5

Ernamaiyanti, Asyari NI, Purba TP. 2016. Analisis daya dukung lahan sektor pertanian berbasis spasial di Nagari Taram Kabupaten Lima Puluh Kota, Sumatera Barat. Gontor AGROTECH Science Journal. 2(2): 21-36. https://doi.org/10.21111/ag rotech.v2i2.411

Kang P, Xu L. 2012. Water environmental carrying capacity assessment of an industrial park. Procedia Environmental Sciences. 13: 879-890. https://doi. org/10.1016/j.proenv.2012.01.082

Krisnamurti, Utami H, Darmawan R. 2016. Dampak pariwisata terhadap lingkungan di Pulau Tidung Kepulauan Seribu. Jurnal Kajian. 21(3): 257-273

Limbong F, Soetomo S. 2014. Dampak perkembangan pariwisata terhadap lingkungan Taman Nasional Karimunjawa. Jurnal Ruang. 22(1): 351-354.

Lu Y, Xu H, Wang Y, Yang Y. 2017. Evaluation of water environmental carrying capacity of city in Huaihe River Basin based on the AHP method: a case in Huai'an City. Water Resources and Industry. 18: 71-77. https://doi.org/10.1016/j.wri.2017.10.001

Moniaga VRB. 2011. Analisis daya dukung lahan pertanian. Agri-Sosioekologi. 7(3): 61-68. https:// doi.org/10.35791/agrsosek.7.2.2011.92

Peraturan Menteri Lingkungan Hidup No. 17 Tahun 2009 tentang Pedoman Penentuan Daya Dukung LH dalam Penataan Ruang Wilayah.

Pratama NA, Widiatmono BR, Wirosoedarmo R. 2016. Evaluasi daya dukung lingkungan berbasis kemampuan lahan di Kota Batu. Jurnal Sumberdaya Alam dan Lingkungan. 2(1): 14-21.

Pramesty AR, Nirmala A, Aspan A. 2014. Perhitungan daya dukung lingkungan berdasarkan ketersediaan air dan produktivitas lahan di Kecamatan Tujuh 
Belas Kabupaten Bengkayang. Jurnal Teknologi Lingkungan Lahan Basah. 1(1): 1-10. https://doi .org/10.26418/jtllb.v2i1.7660

Qian Y, Tang T, Qiu Q, Xu T, Liao J. 2015. A comparative analysis on assessment of land carrying capacity with ecological footprint analysis and index system method: Xiamen. Chinese Academy of Sciences. 10(6): 1-17. https://doi.org /10.1371/journal.pone. 0130315

Rasul G. 2016. Managing the food, water, and energy nexus for achieving the sustainable development goals in South Asia. Environmental Development. 18: 14-19. https://doi.org/10.1016/j.envdev.2015.1 2.001

Rusna IW, Nuarsa IW, Gunadi IGA. 2011. Daya Dukung Lahan. Di dalam: Adnyana IWS, Arthana IW, As-Syakur AR, editor. Denpasar (ID): Pusat Penelitian Lingkungan Hidup. Universitas Udayana. p 65-76.

Santoso DH. 2015. Kajian daya dukung air di Pulau Bintan, Provinsi Kepulauan Riau. Jurnal Sains dan Teknologi Lingkungan. 7(1): 18-28. https://doi.org /10.20885/jstl.vol7.iss1.art2
Sauve S, Bernard S, Sloan P. 2016. Environmental sciences, sustainable development and circular economy: Alternative concepts for trans-disciplinary research. Environmental Development Journal. 17: 48-56. https://doi.org/10.1016/j.envdev.2015.09.00 2

Soemarwoto O. 2001. Ekologi, Lingkungan Hidup, dan Pembangunan. Jakarta (ID): Djambatan. 30-39.

Sudipa N, Mahendra MS, Adnyana WS, Pujaastawa IB. 2020 a. land and water carrying capacity in tourism area of Nusa Penida, Bali. International Journal of Scientific Research and Management. 8(2): 145-161. https://doi.org/10.18535/ijsrm/v8i02.fe-01

Sudipa N, Mahendra MS, Adnyana WS, Pujaastawa IB. 2020b. Tourism impact on the environment in Nusa Penida tourism area. Journal Inveronmental Management and Tourism. 11(41): 113-124. https ://doi.org/10.24843/cs.2020.v13.i03.p01

Wijaya H, Rusdiana O, Tarigan SD. 2017. Daya dukung lingkungan hidup DAS Ciliwung Hulu Kabupaten Bogor. Journal of Environmental. Engineering and Waste Management. 2(1): 25-32. 